\title{
The effect of a titanium socket with a zirconia abutment on screw loosening after thermocycling in an internally connected implant: a preliminary study
}

\author{
Kyu-Young Kyung, Hyun-Suk Cha, Joo-Hee Lee* \\ Department of Prosthodontics, College of Medicine, University of Ulsan, Asan Medical Center, Seoul, Republic of Korea
}

\begin{abstract}
Purpose: The aim of this study was to investigate the effects of a titanium component for the zirconia abutment in the internal connection implant system on screw loosening under thermocycling conditions. Materials and Methods: Internal connection titanium abutments and external connection zirconia abutments with titanium sockets were connected respectively to screwshaped internal connection type titanium implants with $30 \mathrm{Ncm}$ tightening. These implant-screw-abutment assemblies were divided into two groups of five specimens each; titanium abutments as control and zirconia abutments with titanium sockets as experimental group. The specimens were subjected to 2,000 thermocycles in water baths at $5^{\circ} \mathrm{C}$ and $55^{\circ} \mathrm{C}$, with 60 seconds of immersion at each temperature. The removal torque values (RTVs) of the abutment screws of the specimen were measured before and after thermocycling. RTVs pre- and post-thermocycling were investigated in statistics. Results: There was not screw loosening identified by tactile and visual inspection in any of the specimens during or after thermocycling. The mean RTV difference for the control group and the experimental group were $-1.34 \pm 2.53 \mathrm{Ncm}$ and $-1.26 \pm 2.06 \mathrm{Ncm}$, respectively. Statistical analysis using an independent t-test revealed that no significant differences were found in the mean RTV difference of the groups $(P>0.05)$. Conclusion: Within the limitations of this in vitro study, the titanium socket for the zirconia abutment did not show a significant effect on screw loosening under thermal stress compared to the titanium abutment in the internal connection implant. (J Dent Rehabil Appl Sci 2017;33(2):114-8)
\end{abstract}

Key words: screw; abutment; implant; thermocycling; removal torque value

\section{Introduction}

Since esthetic demands of patients increase, it has been accepted to attempt to use zirconia for fabricating prosthetics because of the mechanical properties. However, when choosing abutments for the posterior implant region, zirconia material was not preferred to overcome titanium material. ${ }^{1-3}$ When especially using internally connected zirconia abutments, connection area between the implant and the abutment might be

\footnotetext{
*Correspondence to: Joo-Hee Lee

Associate Professor, Department of Prosthodontics, College of Medicine,

University of Ulsan, Asan Medical Center, 88 Olympicro 43 gil, Songpa-gu, Seoul, 05505, Republic of Korea

Tel: +82-2-3010-5803, Fax: +82-2-3010-6967, E-mail: ljhl11911@hanmail.net

Received: April 25, 2017/Last Revision: May 2, 2017/Accepted: May 9, 2017
}

weak to fracture. ${ }^{4}$ Because of the weak link between the zirconia abutment and the titanium implant, especially in internal type systems, dentists have been somewhat afraid of using zirconia abutments in the posterior implant region.

The introduction of zirconia abutments with a secondary component for internally connected implants was one of major breakthrough endeavors to overcome this weak joint in the zirconia abutment and the implant connections. Such an assembly would be

Copyright@ 2017 The Korean Academy of Stomatognathic Function and Occlusion. (c) It is identical to Creative Commons Non-Commercial License. 
an alternative method for avoiding fracture at the weak point of internally connected zirconia abutments. In one study, superior strength was achieved by means of an internal connection via an additional metal component compared to one-piece zirconia abutment. ${ }^{5}$ In general a secondary component was placed between the abutment and the implant. The titanium socket used in this study had dual hex design needed to fit both the external connection zirconia abutment and the internal connection titanium implant. The zirconia abutment, titanium socket and the implant fixture were all fixated with a single abutment screw without cementation or a friction fitting process. ${ }^{6}$

Abutment screw loosening is one of the most frequent complications that should be resolved in implant dentistry. ${ }^{7}$ This mechanical problem is closely related to the forces that occur between the implant and abutment. The joint separating force that is reciprocal to the clamping force causes screw loosening. The joint separating force is provoked by occlusal parafunction, interproximal contact between the tooth and prosthesis, non-axial occlusal loading, etc. ${ }^{8-10}$ The thermal change that routinely occurs in the oral cavity is also considered to cause the joint separating force and abutment screw loosening because of the different thermal expansion and shrinkage of each implant component. The length, geometry, and material compositions of the implant components including the abutment screw influence the difference in thermal expansion. ${ }^{11}$

The current study intended to investigate the effects of a titanium socket with a zirconia abutment on screw loosening in an internally connected implant under thermocycling conditions in order to determine the relation between screw loosening and a secondary component due to recurring thermal changes.

\section{Materials and Methods}

Two types of implant abutments with the antirotational hex were selected for this study, and were divided into the follows; internal connection titanium abutments (Dual Abutment, Dentium Co., Ltd., Seoul, Korea) and titanium abutment screws as control group, external connection zirconia abutments
(ZirAce External, Acucera Inc., Seoul, Korea) with titanium inserts ( $Z$ socket Regular, Osung MND Co., Ltd., Seoul, Korea) and titanium abutment screws as experimental group (Fig. 1). The titanium abutments were $5.5 \mathrm{~mm}$ in width, $5.5 \mathrm{~mm}$ in height, and 3.5 $\mathrm{mm}$ in collar height. The zirconia abutments were $5.0 \mathrm{~mm}$ in width, $5.5 \mathrm{~mm}$ in height, and $3.0 \mathrm{~mm}$ in collar height. The titanium sockets were $4.1 \mathrm{~mm}$ in width and had dual hexes; a hex which went into an internal connection implant fixture, and an opposite hex which connected to the zirconia abutment (Fig. 2). 10 screw-shaped titanium implants (Implantium,
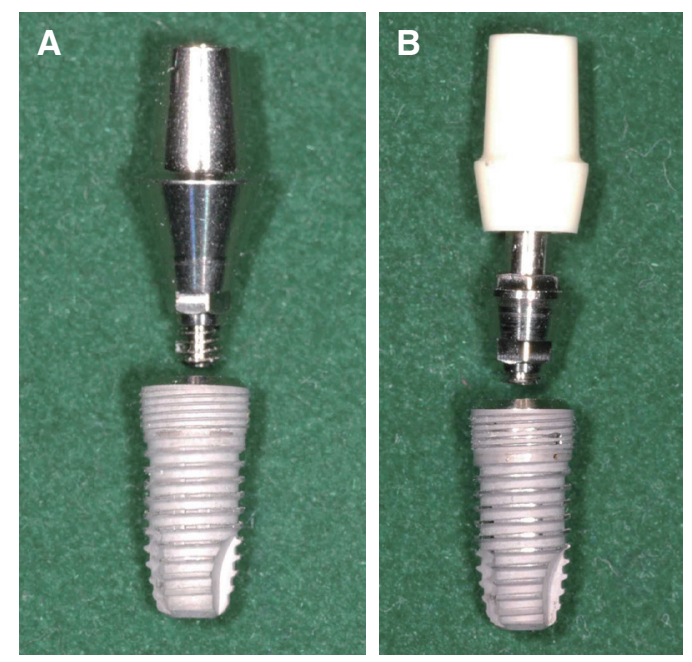

Fig. 1. The implant-abutment assemblies used in the study, (A) Control group: internal connection type titanium implant, titanium abutment, and titanium screw, (B) Experimental group: internal connection type titanium implant, zirconia abutment, titanium socket, and titanium screw.
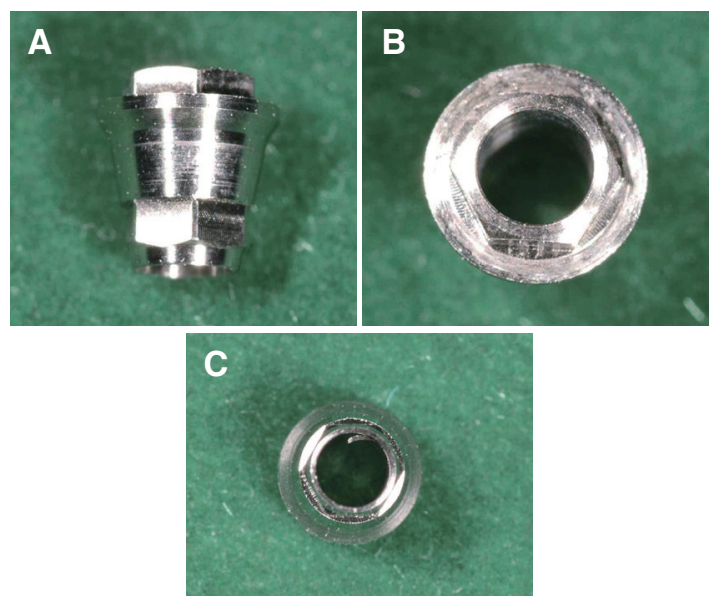

Fig. 2. The view of a titanium socket used in this study. (A) Lateral view, (B) Upper view, (C) Lower view. 
Dentium Co., Ltd.), which were $4.5 \mathrm{~mm}$ in platform diameter, $4.3 \mathrm{~mm}$ in body diameter, and $10.0 \mathrm{~mm}$ in length, were used in this study. The sample size of the abutments was five for each group.

The implants, abutments, and abutment screws were assembled with a tightening torque of $30 \mathrm{Ncm}$, All the specimens were soaked in water in temperatures cycling between $5^{\circ} \mathrm{C}$ and $55^{\circ} \mathrm{C}$ with 60 seconds of dwell time. There was an interval of 35 seconds between the water changes. The cycle was repeated 2,000 times. The removal torque values (RTV) of the specimens were measured with a digital torque gauge (MTT03-12, Mark-10 Co., Hicksville, USA) before and after thermocycling.

The statistical analyses were performed with SPSS 12.0 for Windows (IBM, New York, USA) and $P$ values $<0.05$ were considered statistically significant. To compare RTV differences between the groups, an independent t-test was conducted.

\section{Results}

For all specimens tested, any screw loosening was not identified by visual and tactile inspection during or after the thermocycling. Table 1 lists the prethermocycling and post-thermocycling mean RTVs and the RTV differences. As shown in Table 1, the negative reverse torque difference indicated that thermocycling made the screws required less loosening torque. The control group showed the mean RTV difference value as $-1.34 \pm 2.53 \mathrm{Ncm}$ and the experimental group showed as $-1.26 \pm 2.06 \mathrm{Ncm}$, respectively. Statistical analysis using an independent $\mathrm{t}-$ test revealed that the RTV differences between both groups were not significantly different $(P>0.05)$.

\section{Discussion}

In this study the data suggested that the use of a secondary titanium component for the zirconia abutment did not significantly influence screw loosening under thermal stress compared to the conventional titanium abutment. Clinically, these results would indicate that there is not a mechanical disadvantage due to screw loosening in using the titanium socket to reinforce the zirconia abutment in internally connected implant system.

The titanium socket was mounted on the implant together with the zirconium abutment and fixed by one abutment screw. This titanium socket had dual hexes; a hex which went into an internal connection implant fixture, and an opposite hex which connected to the zirconia abutment. It might be assumed that the external structure of the titanium socket had an influence on the decrease in post-thermocycling $\mathrm{RT}$ values compared to the internally connected titanium implant. However these two values were not statistically significant in this study. One of the complications associated with two-piece zirconia abutments is the instability of the interface between the zirconia abutment and the titanium component depending on how they are connected. Although zirconia abutments seem to exhibit sufficient bending moments when the zirconia abutments are bonded with a titanium socket using resin-luting cements, the cementing procedure itself is a complicating procedure, which could compromise the fracture resistance of the entire zirconia abutment assembly. Therefore, the current abutment assembly design, where a bonding procedure is not necessary, can be a simple and efficient way to reduce future complications.

The zirconia abutments with a titanium socket yielded satisfactory results when compared to titanium abutments with respect to static fracture resistance. ${ }^{6}$ The joint clamping force of an abutment screw in the dental implant structure is generally about $75 \%$ of the maximum tensional strength. ${ }^{12,13}$ Thermocycling was used to simulate the humid

Table 1. Pre-thermocycling and post-thermocycling reverse torque values (RTVs), and RTV differences

\begin{tabular}{cccc}
\hline Group & Pre-thermocycling RTV (mean) & Post-thermocycling RTV (mean) & RTV difference (Ncm) \\
\hline Control & 23.66 & 22.32 & $-1.34 \pm 2.53$ \\
Experimental & 22.74 & 21.48 & $-1.26 \pm 2.06$ \\
\hline
\end{tabular}


conditions and frequent thermal changes of the oral cavity due to saliva and food intake. This study examined the connection between the screw and the abutment after repeated temperature cycling between $5^{\circ} \mathrm{C}$ and $55^{\circ} \mathrm{C}$. The screws and the implants differed with respect to geometry. The stress caused by thermocycling in this study, however, was estimated to be lower than the yielding point since screw loosening was not observed in any specimenrs. ${ }^{1415}$ Further studies will be necessary to evaluate the influence of various clinical conditions on screw loosening for the rationale of using the titanium component in the zirconia abutment while controlling for torque.

\section{Conclusion}

This study investigated the effect of a titanium component for the zirconia abutment in the internal connection system on screw loosening under thermocycling conditions. The titanium socket for the zirconia abutment did not show a significant effect on screw loosening under thermal stress compared to the titanium abutment in the internal connection implant. Within the limitations of this study, the use of a titanium socket cannot be clinically harmful, particularly if internally connected implant system is chosen.

\section{ORCID}

Joo-Hee Lee http://orcid.org/0000-0002-7907-3098

\section{References}

1. Yildirim M, Fischer H, Marx R, Edelhoff D. In vivo fracture resistance of implant-supported allceramic restorations. J Prosthet Dent 2003;90:32531.

2. Apholt W, Bindl A, Lüthy H, Mörmann WH. Flexural strength of Cerec 2 machined and jointed InCeram-Alumina and InCeram-Zirconia bars. Dent Mater 2001;17:260-7.

3. Garvie RC, Hannink RH, Pascoe RT. Ceramic steel? Nature 1975;258:703-4.

4. Adatia ND, Bayne SC, Cooper LF, Thompson JY. Fracture resistance of yttria-stabilized zirconia den- tal implant abutments. J Prosthodont 2009;18:1722.

5. Sailer I, Sailer T, Stawarczyk B, Jung RE, Hämmerle CH. In vitro study of the influence of the type of connection on the fracture load of zirconia abutments with internal and external implant-abutment connections. Int J Oral Maxillofac Implants 2009;24:850-8.

6. Chun HJ, Yeo IS, Lee JH, Kim SK, Heo SJ, Koak JY, Han JS, Lee SJ. Fracture strength study of internally connected zirconia abutments reinforced with titanium inserts. Int J Oral Maxillofac Implants 2015;30:346-50.

7. Ekelund JA, Lindquist LW, Carlsson GE, Jemt T. Implant treatment in the edentulous mandible: a prospective study on Brånemark system implants over more than 20 years. Int J Prosthodont 2003; 16:602-8

8. Eckert SE, Meraw SJ, Cal E, Ow RK. Analysis of incidence and associated factors with fractured implants: a retrospective study. Int J Oral Maxillofac Implants 2000;15:662-7.

9. Taylor TD, Agar JR, Vogiatzi T. Implant prosthodontics: current perspective and future directions. Int J Oral Maxillofac Implants 2000;15:66-75.

10. Winkler S, Ring K, Ring JD, Boberick KG. Implant screw mechanics and the settling effect: overview. J Oral Implantol 2003;29:242-5.

11. Halliday D, Resnick R, Walker J. Fundamentals of physics extended, 8th ed. Hoboken; Wiley; 2008. p. 586-91.

12. McGlumphy EA, Mendel DA, Holloway JA. Implant screw mechanics. Dent Clin North Am 1998; 42:71-89.

13. Burguete RL, Johns RB, King T, Patterson EA. Tightening characteristics for screwed joints in osseointegrated dental implants. J Prosthet Dent 1994;71:592-9.

14. Traini T, Di Iorio D, Caputi S, Degidi M, Iezzi G, Piattelli A. In vitro evaluation of thermomechanic coupling in conical implant-to-abutment joint. Implant Dent 2007;16:379-86

15. Low D, Sumii T, Swain M. Thermal expansion coefficient of titanium casting. J Oral Rehabil 2001; 28:239-42. 


\section{내부연결 임플란트용 타이타늄 소켓을 이용한 지르코니아 지대주에서 열순환이 나사풀림에 미치는 영향: 예비연구}

\section{경규영, 차현석, 이주희}

울산대학교 의과대학 서울아산병원 치과보철과

목적: 이 연구의 목적은 타이타늄 구성요소를 가진 지르코니아 지대주가 내부연결 임플란트에 사용되었을 때 나사 풀림 에 대해 알아보는 것이다. 열순환 후 타이타늄 소켓을 가진 지르코니아 지대주와 타이타늄 지대주의 나사 풀림과 제거력 을 비교 분석하였다.

연구 재료 및 방법: 내측연결 임플란트와 내측연결 타이타늄 지대주, 타이타늄 소켓을 가진 외측연결 지르코니아 지대주 를 준비하였다. 내부연결형 임플란트에 5 개의 타이타늄 지대주를(대조군), 타이타늄 소켓을 가진 5 개의 지르코니아 지대 주(실험군)를 각각 연결하고 $30 \mathrm{Ncm}$ 의 토크로 조인 후 열순환 처리 전후의 지대주 나사 제거력을 측정하였다. 각 시편들 은 열순환 장치의 수조에서 $5^{\circ} \mathrm{C}$ 와 $55^{\circ} \mathrm{C}$ 의 물에 60 초씩 교대로 2,000 회의 열순환을 시행하였다. 각 시편의 나사 풀림을 조사하고 열순환 전후에 나사 제거력을 통계학적으로 분석하였다.

결과: 두 그룹 모두에서 열순환 후 지대주 나사 풀림을 보이지 않았다. 열순환 전후의 나사 제거력 차이는 대조군에서 $-1.34 \pm 2.53 \mathrm{Ncm}$, 실험군에서 $-1.26 \pm 2.06 \mathrm{Ncm}$ 로 나타났다. 독립표본 $\mathrm{T}$ 통계분석 결과 두 군간에 유의한 차이를 보 이지 않았다 $(P>0.05)$.

결론: 이 실험의 결과 내에서 내부연결 임플란트를 위한 지르코니아 지대주 내 타이타늄 소켓이 열순환 후 지대주 나사 풀림에 타이타늄 지대주와 비교하여 유의한 영향을 나타내지 않았다.

주요어: 나사; 지대주; 임플란트; 열순환; 제거력 